Book Review

\title{
Bolaños, Paolo A., \\ Nietzsche and Adorno on Philosophical Praxis, Language, and Reconciliation: Towards an Ethics of Thinking ${ }^{1}$
}

Anton Heinrich L. Rennesland

$\mathrm{P}$ aolo A. Bolaños' latest book, Nietzsche and Adorno on Philosophical Praxis, Language, and Reconciliation: Towards an Ethics of Thinking, attempts to experiment with both Nietzsche and Adorno to present an ethics of thinking. ${ }^{2}$ This type of experimentation accentuates two underdeveloped research areas: Nietzsche's influence on Adorno and the Romantic tradition's influence on both Nietzsche and Adorno. In such undertaking, one immediately recognizes how this experimentation is a mimetic practice. In writing this review, I found it apt to conduct my own experiment with his presentation trough a musical reference that coincides with where Bolaños commences.

In classical music, a fugue is a compositional technique that highlights a musical theme or a subject that begins the piece and which is imitated throughout the entire piece by various voices or instruments. This type of imitation though is not just a straightforward repetition but one marked by a profound tension in the counterpoints that give an overarching polyphonic structure despite tonal differences. ${ }^{3}$ Listeners therefore encounter the subject's presence throughout the piece despite the nonidenticality to what was originally played at the piece's introduction. I would even say that the subject's return throughout the piece is due to the mimetic relationship of all the notes played together and even the subject's relation to the entire piece. This mimetic structure in musical history has been reduced today to the verse-chorus-verse-bridge-chorus structure. There is always a return to the

\footnotetext{
${ }^{1}$ Lanham, MD: The Rowman \& Littlefield Publishing Group, 2021, 210pp..

2 See ibid., xxii.

${ }^{3}$ See Gregory Barnett, "Tonal organization in seventeenth-century music theory," in The Cambridge History of Western Music, ed. by Thomas Christensen (Cambridge: Cambridge University Press, 2008), 418-419.
}

(c) 2021 Anton Heinrich L. Rennesland

https://www.kritike.org/journal/issue 28/rennesland2 june2021.pdf

ISSN 1908-7330

(c) BY-NC-ND 


\section{NIETZSCHE AND ADORNO}

chorus, a return to what is popular. This structure, however, has forgotten the subject. The fugal technique reached a climax in public appreciation in the baroque years and was less favored during the $18^{\text {th }}$ century, coinciding with the emergence of the Frühromantik (Early German) tradition which Bolaños tackles in the first chapter of the book. Just when this technique was less favored, Bolaños' book asserts a lesson that we may surmise from this musical technique: thought is precisely fugal in nature. It returns differently, yet the same. However, just as the contemporary listener has forgotten about the fugal subject, so too has the contemporary thinker forgotten this primal quality of thought. Thought has become estranged in the rubble of what is different (what is the newest craze), in the rubble of what is identical (what is simply pleasing to all). In this case, it is where the caricature of German Romanticism emerges as the pristine all-encompassing longing for the return to the chorus, to the identical, the popular. Yet, this is not what this book presents. In fact, Nietzsche and Adorno, Bolaños shows, is critical of this subsuming identitarian thrust for it is not the temperament they inherit from the Frühromantik tradition, evident in the writings of Hamann, Schelling, Novalis, and the Schlegel brothers to name a few. ${ }^{4}$

In history, the subject has been weakened - this has been a crisis in philosophy. ${ }^{5}$ We have forgotten the entire point of the fugue, of the mimetic relationship in the counterpoint of the various tones, and above all of the subject to reality. This is what the nonidentical relationship posits to salvage especially beyond communicative rationality: it goes beyond the human to the nonhuman. ${ }^{6}$ In fact, it is for this reason that exposing the caricature of romanticism remains a strong point of this book. Early German Romanticism emphasized education as enlightenment, political engagement, and aesthetical insight. The poetic distance of nature to the self allows one to realize how the subject is an integral (not focal) part of the nonhuman reality. Overall, what the Romantic thinkers sought to point out was the sensitivity to the nonidentical relation of subject and object, thoughts and material representation, and ultimately, the summum bonum. ${ }^{7}$ It is in relation to this that the seven features of early German Romanticism - namely, 1) the unity of philosophy and poetry, (2) the importance of education or Bildung, (3) the poetic treatment of nature, (4) freedom in writing style, (5) the constitutive relation between language and thinking, (6) Romantic irony, and (7) philosophical anti-foundationalism - form Bolaños' link of Romanticism to Nietzsche and Adorno since, via Nikolas Kompridis' framing of the romantic legacy, outlining its features reclaims the subject from thought's rubble and

4 See Bolaños, Nietzsche and Adorno, 3.

${ }^{5}$ See Ibid., 5.

${ }^{6}$ See Ibid., 78.

${ }^{7}$ Ibid. 8.

(c) 2021 Anton Heinrich L. Rennesland

https://www.kritike.org/journal/issue 28/rennesland2 june2021.pdf

ISSN 1908-7330

(cc) BY-NC-ND 
enlarges its receptivity contrasted to a reified caricature of thought's identitarian return. ${ }^{8}$ Yet, what remains to be the challenge from such a presentation is the persistence of the lasting legacy; we ought to relearn from the fugue so that we become receptive to the early Romantic heritage and to refuse a "fixation with a singular, and often insular, language that leaves out possibilities while at the same time unconsciously harboring intellectual obscurantism and, indeed, dangerous dogmatism." ${ }^{9}$ Relearning these seven features of early German Romanticism present a greater capacity of a critique of language.

As this book established, Nietzsche and Adorno pursued this critique of a language that reflects identity-thinking in their own respective philosophical enterprises. Bolaños' presentation of Nietzsche's critique of language seems to follow his earlier impression of Nietzsche's critique of nihilism that lies at heart of the philosopher's ethics of affirmation. ${ }^{10}$ In this current book, however, what is novel is a more serious engagement with Nietzsche's own treatment of language, specifically the role of metaphors in his philosophy. Bridging the two works, one may surmise how "Nietzsche's aphoristic style is a conscious exercise of philosophical praxis" which becomes the basis of his ethics of affirmation. ${ }^{11}$ Nietzsche's metaphorical language bears testament to the necessity of illusions in that they are lifeaffirming. This revaluation of not just values but also of speech, is made possible by Nietzsche's mindfulness of a profound pathos of distance that fundamentally informs life. It is something Nietzsche inherits, as Bolaños points out, from the German Romantic tradition and is something also found in Adorno's works. Conversely, the pathos of distance in Adorno's writings allows us to recognize the wrong state of things, implying that language must always remain critical as this serves as the primary means philosophy has to convey critique. ${ }^{12}$ Perhaps, this casts light upon Adorno's reluctance to join Marcuse's Great Refusal or rather playfully, Adorno's tacit comprehension of why Dante alluded such an act to the unnamed coward in the Inferno. ${ }^{13}$ Rather than a refusal, negative dialectics is Adorno's preference as it is a struggle to remain conscious of the mimetic receptivity of philosophy that saves it from reification. ${ }^{14}$ Thinking must leave space for life, both the human and the nonhuman reality.

\footnotetext{
8 See Ibid., 19-23.

${ }^{9}$ Ibid., 23.

10 See Paolo A. Bolaños, On Affirmation and Becoming: A Deleuzian Introduction to Nietzsche's Ethics and Ontology (Newcastle upon Tyne: Cambridge Scholars Publishing, 2014), 81.

${ }^{11}$ Bolaños, Nietzsche and Adorno, 63.

12 See Ibid., 88.

${ }^{13}$ See Dante Alighieri, Inferno, in The Divine Comedy Volume 1, ed. and trans. by Robert T. Durling (New York: Oxford University Press, 1996), Canto 3, lines 58-60, 57.

${ }^{14}$ See Bolaños, Nietzsche and Adorno, 91.
} 


\section{NIETZSCHE AND ADORNO}

Perhaps, we ought to learn once more from the mimesis which the fugue was able to instill in popular consciousness then: the early German Romanticists, Nietzsche, and Adorno repeated the subject; this book is Bolaños' own effort to repeat the same but different subject. What this book reminds us of is the importance of an immanent critique of language and of the subject's return that saves thought from confusion between first and last, what persists and what perishes, and even concept and object. ${ }^{15}$ It is mindful of its very own material conditions, similar to my fugal imagery of how the subject returns differently, having altered to the current key or even time signature. In my own minute experiment with Bolaños' opus, we see that the diminishment of the fugue from popular consciousness is indicative of a society's forgetfulness of the subject, a forgetfulness of the mimetic relationship that invokes an aesthetic experience. Today, in a world entrenched in limitless mobility and speed, mimesis-inherited from the Frühromantik tradition-teaches us the importance of dwelling, of lingering. Being unable to linger is the deception and inhumanity of idealism in hypostasizing concepts, the tantalizing effect of literal speech, the reification of our own ideas. ${ }^{16}$ This book presents how both Nietzsche and Adorno lingered in reality, which prompted their own critical insight into the tantalizing effects of language - be it in the form of truth for Nietzsche or reification for Adorno - and opened them to a sensitivity to the nonidentical.

To cap my experimentation, it is rather unfortunate that society may not have fully learned from the fugue. More so, it is unfortunate that society has nearly forgotten about it. From Johann Sebastian Bach's Fugue in D minor or even Dmitri Shostakovich's Waltz no. 2, it would not be unsurprising if our own memory of these is from a Phantom of the Opera scene and a background melody from some cartoon interlude respectively. Maybe its demise is due to a misunderstanding of identity and difference that eternally return in the fugue; the play of contradictions we hail to find home in postmodernism in fact took root and was significantly appreciated by society in the 1500s. We just scratch upon the surface of identity and difference if we only seek recourse to caricatures of the philosophies of Deleuze or Derrida by their self-professed followers and even of Adorno, Nietzsche, and German Romanticism. ${ }^{17}$ This is even extended to the entire plethora of philosophy from Plato to Susan Bordo or from Zhuang Zi to Richard David Precht that permeate national boundaries and traverse disciplines. We fail to learn from philosophy when we simply live with caricatures - Nietzsche as a nihilist and Adorno as an ivory-tower philosopher - and do not hollow out our dead idols or when we fail view reality from a damaged life.

${ }^{15}$ See Ibid., 147.

${ }^{16}$ See Ibid., xix.

${ }^{17}$ See Ibid., 5.

(c) 2021 Anton Heinrich L. Rennesland

https://www.kritike.org/journal/issue 28/rennesland2 june2021.pdf

ISSN 1908-7330

(cc) BY-NC-ND 
With the demise of the fugue came sonatas and symphonic melodies. Perhaps my experimentation is best to end with this narrative: the fugue's demise paved the way for the Fourth Movement of Ludwig van Beethoven's Ninth Symphony which puts to tune Friedrich Schiller's poem An die Freude. This poem, popularized by the symphony, presents a utopic vision, and, rather blissfully, one may perhaps conjure that after the educative and performative functions of the fugue came a tension (and to an extent an epistemic and political tension) with utopia. ${ }^{18}$ This type of utopia perhaps is what Bolaños mentions as a "cognitive utopia" that is "the reconciliation of the mind and body, subject and object." 19 The symphony provides its own narrative unlike the fugue which puts to stage the subject to return. Arguably, the composition of Beethoven's symphony was the pinnacle of the fugue's success for only after the fugues of Johann Sebastian Bach, Johann Pachelbel, and Dieterich Buxtehude can the cognitive utopia of where "all beings drink joy at nature's breast" can be realized. ${ }^{20}$ All beings, both human and nonhuman, enter this cognitive utopia drunk with fire (feuertrunken) and become siblings beyond what positivist epistemology divides with the sword. Because of the mimetic language, reality ceases to be reduced to truth or identity-thinking in relation to Nietzsche and Adorno respectively. Through such an approach, cognitive utopia becomes not solely fantasizing but a "recovery of experience" through a "cognitive openness" especially to the nonhuman as a glimpse of inverted theology. ${ }^{21}$

Lastly, it deserves to be said that this book is testament to the deepening quality of how philosophy is being done in the Philippines. This is evident for several reasons: first, Bolaños' direct responses to the criticisms of Adorno by Jürgen Habermas, Maeve Cooke, and Rüdiger Bittner; second, his reconstruction of the link from the Frühromantik tradition to Nietzsche and to Adorno; and thirdly, his reconstruction of Nietzsche and Adorno's own theories of language. The fact that the book contributes to at least three different areas of study speaks of the earnest contribution of a Filipino scholar to the global philosophical landscape; something that, I believe, should be recognized by other Filipino scholars. Those who say that philosophy in the Philippines is still at the level of translation or of writing textbooks have obviously not read any of the recent works by our scholars and are earnestly invited to read this book.

18 See Nicholas Cook, Beethoven: Symphony No. 9 (Cambridge: Cambridge University Press, 1993), 16, 101-105.

${ }^{19}$ Bolaños, Nietzsche and Adorno, 110.

${ }^{20}$ Friedrich Schiller, "An die Freude," in Cook, Beethoven: Symphony No. 9, Appendix I, 108. Translation is mine.

${ }^{21}$ See Bolaños, Nietzsche and Adorno, 110.

(c) 2021 Anton Heinrich L. Rennesland https://www.kritike.org/journal/issue 28/rennesland2 june2021.pdf

ISSN 1908-7330 


\section{NIETZSCHE AND ADORNO}

Overall, Bolaños presents in four chapters (exclusive of the introduction and the conclusion) an attempt at providing an ethics of thinking by reconstructing Nietzsche and Adorno's philosophy of language. This experimentation with the two philosophers engages their own respective critiques of language found in Nietzsche's Nachlass and Adorno's "Theses on the Language of the Philosopher" and "The Actuality of Philosophy" besides other texts. Those who have no prior knowledge of German Romanticism, Nietzsche, or Adorno might find this book complicated since it offers a reconstruction on several levels. However, such a reconstruction allows this book to be an engaging reading to the accustomed reader as it provides various ideas for further discussion ranging from German Romanticism to Adorno's inverted theology. This book presents a novel way to read, nay experiment, with these philosophers.

Department of Philosophy, University of Santo Tomas, Philippines

\section{References}

Alighieri, Dante. Inferno, in The Divine Comedy Volume 1, ed. and trans. by Robert T. Durling (New York: Oxford University Press, 1996).

Barnett, Gregory. "Tonal organization in seventeenth-century music theory," in The Cambridge History of Western Music, ed. by Thomas Christensen (Cambridge: Cambridge University Press, 2008), 418-419.

Bolaños, Paolo A. Nietzsche and Adorno on Philosophical Praxis, Language, and Reconciliation: Towards an Ethics of Thinking (Lanham, MD: The Rowman \& Littlefield Publishing Group, 2021).

On Affirmation and Becoming: A Deleuzian Introduction to Nietzsche's Ethics and Ontology (Newcastle upon Tyne: Cambridge Scholars Publishing, 2014).

Cook, Nicholas. Beethoven: Symphony No. 9 (Cambridge: Cambridge University Press, 1993). 